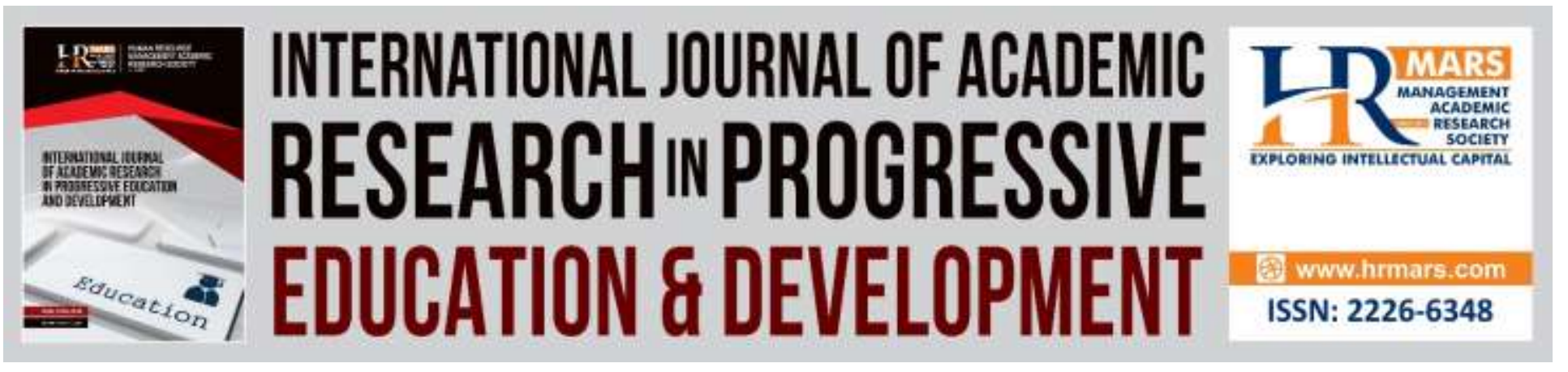

\title{
FrogPlay as Gamification Tool in Motivating and Engaging School Students: An Analyses Review
}

\section{Shariful Hafizi bin Md Hanafiah, Kamarul Shukri bin Mat Teh}

To Link this Article: http://dx.doi.org/10.6007/IJARPED/v8-i2/5692

DOI: $10.6007 /$ IJARPED/v8-i2/5692

Received: 06 March 2019, Revised: 23 April 2019, Accepted: 03 May 2019

Published Online: 10 May 2019

In-Text Citation: (Hanafiah \& Teh, 2019)

To Cite this Article: Hanafiah, S. H. bin M., \& Teh, K. S. bin M. (2019). FrogPlay as Gamification Tool in Motivating and Engaging School Students: An Analyses Review. International Journal of Academic Research in Progressive Education and Development, 8(2), 168-175.

Copyright: (C) 2019 The Author(s)

Published by Human Resource Management Academic Research Society (www.hrmars.com)

This article is published under the Creative Commons Attribution (CC BY 4.0) license. Anyone may reproduce, distribute, translate and create derivative works of this article (for both commercial and non-commercial purposes), subject to full attribution to the original publication and authors. The full terms of this license may be seen at: http://creativecommons.org/licences/by/4.0/legalcode

Vol. 8(2) 2019, Pg. 168 - 175

http://hrmars.com/index.php/pages/detail/IJARPED

JOURNAL HOMEPAGE

Full Terms \& Conditions of access and use can be found at http://hrmars.com/index.php/pages/detail/publication-ethics 


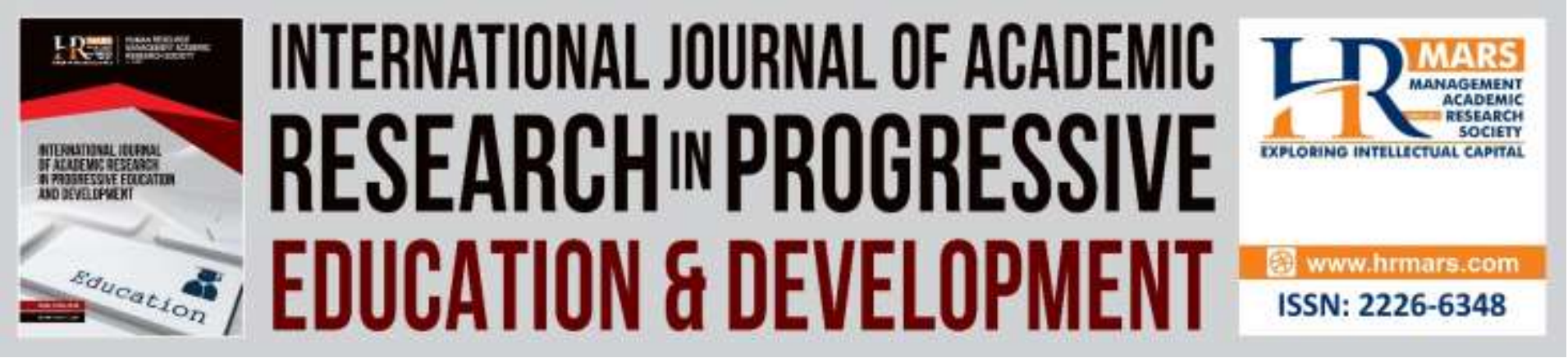

\title{
FrogPlay as Gamification Tool in Motivating and Engaging School Students: An Analyses Review
}

\author{
Shariful Hafizi bin Md Hanafiah, Kamarul Shukri bin Mat Teh (PhD) \\ Faculty of Islamic Contemporary Studies, Sultan Zainal Abidin University (UNISZA), \\ Terengganu, Malaysia
}

\begin{abstract}
In this $21^{\text {st }}$ century, the use of educational technology has been evolved and civilizing the educational sector. Hence, the Malaysia Ministry of Education (MoE) has been revamped educational curriculum in order to enrich and incorporate information communications and technology (ICT). When integrating ICT into teaching and learning sessions, proved through some educational technology research, it has shown an improvement in the motivation and engagement of students. Furthermore, the full extent capability of educational technology could not be optimized since integrating ICT in education blended with several problems such as misconception about technology use in teaching and learning amongst the teachers, difficulty in accessing to the technology itself and disengagement of students in the classroom during learning sessions. As an alternative to overcome difficulties integrating ICT in education, by integrating games and technology in education has produced offshoots such as game-based learning, serious games and more recently gamification. Gamification refers to the presence of gameful experience to existing systems (example: education) as opposed to creating entirely new or full-fledged games. Gamification paves the way for easier implementation as a tool in motivating and engaging school students. Therefore this paper will discuss the role of FrogPlay as gamification tool in motivating and engaging school students; based on analyses review of several kinds of literature.
\end{abstract}

Keywords: FrogPlay, gamification, motivation, engagement, students.

\section{Introduction}

Docebo (2016) has reported and demonstrated that e-learning market size is worth more than USD165 billion in 2015 and is targeted to grow by 5\% between 2016-2023 with an estimated value reaching USD 240 billion. Among the other interesting things, (Docebo, 2016) has predicted growth in e-learning is the influence and use of gamification. Gamification has been defined as the use of designs, elements and features of video games beyond its context (Deterding, Khaled, Nacke, \& Dixon, 2011). Newzoo (2016) also recorded Malaysia's population are 30.8 million, of which 22.8 million or $65 \%$ of them were classified as online population. This proves the opportunity and the 
potential of gamification in education to be explored, researched and used in line with the development of e-learning.

Gamification is a prominent trend in recent years, where gamification uses gamification experience beyond the context of video games (Eppmann, Bekk, \& Klein, 2018). In order to prove this trend of gamification are figures 1.1 and 1.2 that have been acquired through the Google Trends website (https://trends.google.com/trends/). Figure 1.1 illustrates the trends and popularity of gamification terms around the globe over the last 10 years from 2008 to 2018 while figure 1.2 illustrates the trend and popularity of gamification terms over the same period in Malaysia.

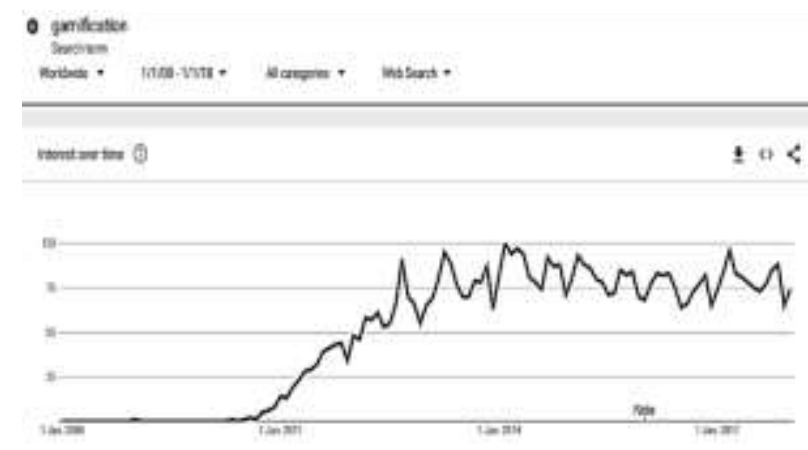

Figure 1.1: Trends and popularity of gamification search terms worldwide for the last 10 years (2008-2017).
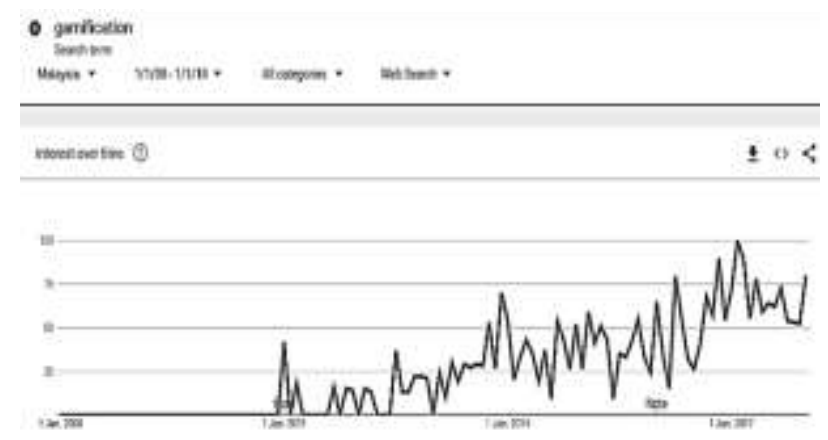

Figure 1.2: Trends and popularity of gamification search terms in Malaysia for the last 10 years (2008-2017).

The figures on the left of the two graphs represent an interest over time compared to the highest points on the graph for the region (worldwide and Malaysia) starting from 2008 to 2017. Value 100 means that most popularity of this term while value 50 means that the term is half popular whereas value 0 means there is not enough data for this term. It is evident that gamification has an uptrend in the last 10 years around the globe and Malaysia itself. Gamification has been identified as one of the most important ideas and has the prospect of education (Mahfuzah, Sazilah, \& Norasiken, 2017) and has been termed as gamification in education. Gamification in education is a current strategy that gains popularity in e-learning by using the mechanics and dynamics of video games in education context to increase student motivation and encourage student engagement in learning. (Barna \& Fodor, 2017; Davis, Sridharan, Koepke, Singh, \& Boiko, 2018; Mahfuzah, Safwana, \& Azran, 2018).

\section{Gamification Tool for Motivation and Engagement Purposes}

Dyer (2015) notes that gamification has the potential to be widely used in various fields to solve human life problems because of its capabilities and potential to stimulate motivation and engagement to influence behavioral change (Pedro, Lopes, Prates, Vassileva, \& Isotani, 2015). Hamari, Koivisto, and Sarsa (2014) observed and identified 24 peer-reviewed empirical studies regarding gamification by reporting the outcomes and approaches applied. They concluded because of the different intrinsic and extrinsic motivators associated with the different activities for engagement, the applied gamification was successful and very context-dependent. Also, these 
individuals that are always tangled around with technologies or gadgets in their daily tasks been identified as digital natives (McGonigal, 2011) or as an online population (Newzoo, 2016).

Educational support systems, traditional learning and pedagogical tools might be too restraining and old-fashioned for these digital natives. Hence, different motivational tactics and applications with the means of gamification need to be studied (Mageswaran, Zaleha, \& Norasykin, 2015). Their study focuses on the cognitive impact of different approaches to the gamification to achieve better results by maintaining digitally native generation motivation and engagement. Systematically map study on gamification is applied on learning indicates, most common types of papers either evaluate the existing systems, or offer solutions to the learning problems on motivational changes, improved learning or engagement levels (Borges, Durelli, Reis, \& Isotani, 2014).

Currently, an interactive teaching and learning activities through Game-based Classroom Response System (GCRS) has become one of the trend in gamification (Abidin \& Zaman, 2017) and has gained popularity to the digital generation. In the literature, these technologies also known as electronic voting systems, audience response systems, personal response systems, and classroom response systems (Chaiyo \& Nokham, 2017). These GCRS tools and platforms are based on a quiz concept to facilitate interactive teaching and learning activities. Students score points when they choose the correct answer. Kahoot, Quizizz and Socrative is an example of a GCRS. Through GCRS, students have the opportunity through a fun and engaging atmosphere for self-assessment. By implementing GCRS methods in the class also affect the attendance of the students positively (Abidin \& Zaman, 2017).

Chaiyo and Nokham (2017) stated that students relatively agree that through Kahoot and Quizizz can support their learning by increases their motivation, engagement, concentration and satisfaction. Support their findings also, Wang, Zhu, and Sætre (2016) conducted a survey comparing students using a GCRS with paper forms and a simple non-game-based student. Their survey proved that students using a GCRS are more motivated, engaged and enjoyed their learning. The Recursive Runner GCRS module, where students must play the game in order to complete the lab assignment, a self-build GCRS was designed by Zhang, Atay, Smith, Caldwell, and Jones (2014) to help students understanding and learning better. Their GCRS module experiment recorded that an average for the pretest is lower than the posttest.

\section{FrogPlay: The Gamified Tool for Quizzes}

The gamified quiz software tool, named FrogPlay, was developed and embedded as a webbased application by Frog Asia through their Virtual Learning Environment (VLE) known as Frog VLE (FrogAsia Sdn Bhd, 2016a, 2016b; Shariful Hafizi, Kamarul Shukri, \& Norzehan, 2017). Since the tool was relatively simple for students to use, students were not provided with any substantial training. Instead, they were given a manual, quick tutorial, overview of FrogPlay and its purpose. O'Neil, Wainess and Baker (2005) stated that computer games by themselves are not sufficient for learning to occur. However, to support and enhance student learning within an instructional context can be done by activating certain game elements (Garris, Ahlers, \& Driskell, 2002).

The game-based learning model by Garris et al. (2002) helps teachers to combine and design learning with game features. These game features will trigger a repetitive game cycle that influences student motivation and active involvement in learning. As a result, the impact of student 
high motivation and active engagement in learning session led to a series of specific objective achievement in learning outcomes. Thus, the tool (FrogPlay) was used in a context aimed at continuously motivating students to revise past subject syllabus taught. To ensure and motivate students to learn while making the learning activity enjoyable, FrogPlay (1) presenting questions to students which did not need too much thoughtful with the intention to avoid situating heavy mental or cognitive loads, (2) using time limitation as moderate pressure on students to answer questions, and ( 3 ) encouraging students participation to be voluntary and hence not assessing the activity.

\section{Gamified Learning Activity}

This gamified learning activity, as implemented by Cheong, Cheong, and Filippou (2013), will be composed in two parts, (1) the active students engaging (answering) the quiz and (2) the teacher as an instructor discussed their quiz results with the students. As for the first part, the instructor would start the FrogPlay session by firstly explaining the learning and quiz objectives. The FrogPlay quizzes are not synchronized; where students can start and complete the quiz at different times, depending on how quickly they answer all the questions. As a student completed the quiz, student point (result) will appear on the FrogPlay leaderboard. As a point of excitement and encouraging discussion for students, this leaderboard had the real-time effect of changing player rankings as new results were posted to the board. The leaderboard represents and function as an acknowledgement of student engagement and performance during the quiz sessions.

Another important (second) part of the strategy was the active involvement of teacher as an instructor with students at the wrapping up session. This session occurs after the results are known through the projected leaderboard. During this activity phase, the teacher roles are not simply to go through the questions and answers, but rather to ask students why particular answers were correct or incorrect as a pedagogical way to stimulate students to interest in the learning topic. The further support provided to students with feedback given to them facilitates students comprehension of the topic. Hence, can be perceived as some form of the scaffolding of their learning to achieve learning objectives or outcomes.

\section{Conclusion}

Based on the literature been discussed above, it is crystal proved that gamification can harvest good elements when been use as a tool to influence many aspects of education. Thoroughly discovered in the literature, to compare conventional learning with gamified learning, several differentiations between the two been identified as Table 1 shown. As for Table 2 summarize the literature been discussed in order to prove that FrogPlay can act as gamification tool in motivating and engaging school student in learning. 
INTERNATIONAL JOURNAL OF ACADEMIC RESEARCH IN PROGRESSIVE EDUCATION AND

DEVELOPMENT

Vol. 8, No. 2, 2019, E-ISSN: 2226-6348 C 2019 HRMARS

Table 1. Conventional and gamified learning comparisons

\begin{tabular}{|l|l|}
\hline Conventional Learning & Gamified Learning \\
\hline Teacher teach students & Students self-learning \\
\hline Teacher marks to evaluate students & Points to evaluate students \\
\hline Text via books and boards & More attractive design \\
\hline Topics to define subject or course contents & More competition through levels \\
\hline Increased complexity & More complexity by stages \\
\hline Test & Mastery by level \\
\hline Grade & Rank (example: leaderboard) \\
\hline
\end{tabular}

Table 2. Conventional and gamified learning comparisons

\begin{tabular}{|c|c|c|c|}
\hline Author & Article & $\begin{array}{l}\text { Approach } \\
\text { Tool }\end{array}$ & Results \\
\hline $\begin{array}{l}\text { (Hamari et al., } \\
\text { 2014) }\end{array}$ & $\begin{array}{l}\text { Does gamification work? A } \\
\text { literature review of empirical } \\
\text { studies on gamification }\end{array}$ & $\begin{array}{l}\text { Systematic } \\
\text { literature } \\
\text { review }\end{array}$ & $\begin{array}{l}\text { Positive effect on motivation and } \\
\text { engagement psychological outcomes }\end{array}$ \\
\hline $\begin{array}{l}\text { (Mageswaran et } \\
\text { al., 2015) }\end{array}$ & $\begin{array}{l}\text { Gamification: Cognitive impact and } \\
\text { creating a meaningful experience in } \\
\text { learning }\end{array}$ & $\begin{array}{l}\text { Systematic } \\
\text { literature } \\
\text { review }\end{array}$ & $\begin{array}{l}\text { Most gamification research results } \\
\text { succeeded in motivating and engaging } \\
\text { students }\end{array}$ \\
\hline $\begin{array}{l}\text { (de Sousa } \\
\text { Borges et al., } \\
2014)\end{array}$ & $\begin{array}{l}\text { A systematic mapping on } \\
\text { gamification applied to education }\end{array}$ & $\begin{array}{l}\text { Systematic } \\
\text { mapping study }\end{array}$ & $\begin{array}{l}\text { Discovered that gamification use to } \\
\text { evaluating existing system by offering } \\
\text { solutions in motivational changes, } \\
\text { improved learning or engagement } \\
\text { levels }\end{array}$ \\
\hline $\begin{array}{l}\text { (Abidin \& } \\
\text { Zaman, 2017) }\end{array}$ & $\begin{array}{l}\text { Students' perceptions on game- } \\
\text { based classroom response system } \\
\text { in a computer programming course }\end{array}$ & Kahoot & $\begin{array}{l}\text { More than } 90 \% \text { of students agree using } \\
\text { Kahoot motivates and engaging them in } \\
\text { learning }\end{array}$ \\
\hline $\begin{array}{l}\text { (Chaiyo \& } \\
\text { Nokham, 2017) }\end{array}$ & $\begin{array}{l}\text { The effect of Kahoot, Quizizz and } \\
\text { Google Forms on the student's } \\
\text { perception in the classrooms } \\
\text { response system }\end{array}$ & $\begin{array}{l}\text { Kahoot, Quizizz } \\
\text { and Google } \\
\text { forms }\end{array}$ & $\begin{array}{l}\text { Kahoot and Quizizz support students } \\
\text { learning by increasing their motivation, } \\
\text { engagement, concentration and } \\
\text { satisfaction }\end{array}$ \\
\hline $\begin{array}{l}\text { (Wang et al., } \\
\text { 2016) }\end{array}$ & $\begin{array}{l}\text { The effect of digitizing and } \\
\text { gamifying quizzing in classrooms }\end{array}$ & $\begin{array}{l}\text { Paper, Clicker } \\
\text { and Kahoot }\end{array}$ & $\begin{array}{l}\text { Students using Kahoot compared to } \\
\text { paper form and simple non-game- } \\
\text { based system (Clicker) were more } \\
\text { motivated, engaged, concentrated and } \\
\text { enjoyed more in learning }\end{array}$ \\
\hline $\begin{array}{l}\text { (Zhang et al., } \\
\text { 2014) }\end{array}$ & $\begin{array}{l}\text { Using a game-like module to } \\
\text { reinforce student understanding of } \\
\text { recursion }\end{array}$ & $\begin{array}{l}\text { The Recursive } \\
\text { Runner }\end{array}$ & $\begin{array}{l}\text { Students understand better through } \\
\text { learning support by games. }\end{array}$ \\
\hline
\end{tabular}

\section{Corresponding Author}

Shariful Hafizi bin Md Hanafiah; Faculty of Islamic Contemporary Studies, Sultan Zainal Abidin University, Malaysia

Email: sharifulhafizi@gmail.com 
INTERNATIONAL JOURNAL OF ACADEMIC RESEARCH IN PROGRESSIVE EDUCATION AND

DEVELOPMENT

Vol. 8, No. 2, 2019, E-ISSN: 2226-6348 @ 2019 HRMARS

\section{References}

Abidin, H. Z., \& Zaman, F. H. K. (2017). Students' perceptions on game-based classroom response system in a computer programming course. In 2017 IEEE 9th International Conference on Engineering Education (ICEED) (hal. 254-259). https://doi.org/10.1109/ICEED.2017.8251203

Barna, B., \& Fodor, S. (2017). An Empirical Study on the Use of Gamification on IT Courses at Higher Education. In M. E. Auer, D. Guralnick, \& I. Simonics (Ed.), Teaching and Learning in a Digital World. ICL 2017 (Vol. 715, hal. 684-692). Springer, Cham. https://doi.org/10.1007/978-3-31973210-7

Chaiyo, Y., \& Nokham, R. (2017). The effect of Kahoot, Quizizz and Google Forms on the student's perception in the classrooms response system. 2nd Joint International Conference on Digital Arts, Media and Technology 2017: Digital Economy for Sustainable Growth, ICDAMT 2017, 178-182. https://doi.org/10.1109/ICDAMT.2017.7904957

Cheong, C., Cheong, F., \& Filippou, J. (2013). Quick Quiz: A Gamified Approach for Enhancing Learning. PACIS 2013 Proceedings, 1-14. https://doi.org/pacis2013/206

Davis, K., Sridharan, H., Koepke, L., Singh, S., \& Boiko, R. (2018). Learning and engagement in a gamified course: Investigating the effects of student characteristics. Journal of Computer Assisted Learning, (September 2017), 1-12. https://doi.org/10.1111/jcal.12254

Borges, D. S., Durelli, V. H. S., Reis, H. M., \& Isotani, S. (2014). A systematic mapping on gamification applied to education. In Proceedings of the 29th Annual ACM Symposium on Applied Computing (hal. 216-222). ACM.

Deterding, S., Khaled, R., Nacke, L., \& Dixon, D. (2011). Gamification: toward a definition. Chi 2011, 12-15. https://doi.org/978-1-4503-0268-5/11/0

Docebo. (2016). ELearning Market Trends and Forecasts 2017-2020. Docebo.

Dyer, R. (2015). A conceptual framework for gamification measurement. In Gamification in Education and Business (hal. 47-66). https://doi.org/10.1007/978-3-319-10208-5_3

Eppmann, R., Bekk, M., \& Klein, K. (2018). Gameful Experience in Gamification: Construction and Validation of a Gameful Experience Scale [GAMEX]. Journal of Interactive Marketing, 43, 98115. https://doi.org/10.1016/j.intmar.2018.03.002

FrogAsia Sdn Bhd. (2016a). FrogPlay - Panduan Produk (Guru). Frog Asia Sdn Bhd.

FrogAsia Sdn Bhd. (2016b). FrogPlay - Panduan Produk (Murid). FrogAsia Sdn Bhd.

Garris, R., Ahlers, R., \& Driskell, J. E. (2002). Games, Motivation, and Learning: A Research and Practice Model. Simulation \& Gaming, 33(4), 441-467.

https://doi.org/10.1177/1046878102238607

Hamari, J., Koivisto, J., \& Sarsa, H. (2014). Does gamification work?--a literature review of empirical studies on gamification. System Sciences (HICSS), 2014 47th Hawaii International Conference on, 3025-3034. https://doi.org/10.1109/HICSS.2014.377

Mageswaran, S., Zaleha, A., \& Norasykin, M. Z. (2015). Gamification: Cognitive impact and creating a meaningful experience in learning. ICEED 2014 - 2014 IEEE 6th Conference on Engineering Education, 123-128. https://doi.org/10.1109/ICEED.2014.7194700

McGonigal, J. (2011). Reality is Broken: Why Games Make Us Better and How They Can Change the World. New York. https://doi.org/10.1075/ni.10.1.03bro

Newzoo. (2016). 2016 Global Games Market Report: An Overview of Trends \& Insights. 
O’Neil, H. F., Wainess, R., \& Baker, E. L. (2005). Classification of learning outcomes: evidence from the computer games literature. Curriculum Journal, 16(4), 455-474. https://doi.org/10.1080/09585170500384529

Pedro, L. Z., Lopes, A. M. Z., Prates, B. G., Vassileva, J., \& Isotani, S. (2015). Does gamification work for boys and girls? Proceedings of the 30th Annual ACM Symposium on Applied Computing SAC'15, 214-219. https://doi.org/10.1145/2695664.2695752

Hafizi, S. M. H., Kamarul Shukri, M. T., \& Norzehan, A. K. (2017). Implementasi model gamifikasi pembelajaran ARCS + G dalam aplikasi FrogPlay. In Seminar Pedagogi dan Pengurusan Pendidikan Kebangsaan: Amalan Terbaik dalam Pedagogi dan Pengurusan Pendidikan (hal. 128-140). Institut Pendidikan Guru Kampus Sultan Mizan.

Wang, A. I., Zhu, M., \& Sætre, R. (2016). The effect of digitizing and gamifying quizzing in classrooms. Academic Conferences and Publishing International.

Zhang, J., Atay, M., Smith, E., Caldwell, E. R., \& Jones, E. J. (2014). Using a game-like module to reinforce student understanding of recursion. In Frontiers in Education Conference (FIE), 2014 IEEE (hal. 1-7). IEEE. 